\title{
A retrospective analysis of 34 potentially missed cases of female genital mutilation in the emergency department
}

\author{
Richard John Fawcett, ${ }^{1,2}$ George Kernohan ${ }^{2,3}$
}

\begin{abstract}
- Additional material is published online only. To view, please visit the journal online (http://dx.doi.org/10.1136/ emermed-2017-206649).

'Emergency Department, Royal Stoke University Hospital, Stokeon-Trent, UK

${ }^{2}$ Faculty of Life Sciences and Education, University of South Wales, Pontypridd, UK

${ }^{3}$ Institute of Nursing and Health Research, University of Ulster, Coleraine, UK
\end{abstract}

Correspondence to Dr Richard John Fawcett, Emergency Department, Royal Stoke University Hospital,Newcastle Road, Stokeon-Trent ST4 6QG, UK; Richard.fawcett@uhnm.nhs.uk

Received 1 February 2017 Revised 24 June 2017 Accepted 31 July 2017 Published Online First 12 September 2017

\section{Linked}

- http://dx.doi.org/10.1136/ emermed-2018-207994

Check for updates

To cite: Fawcett RJ, Kernohan G. Emerg Med J 2018:35:587-589.

\begin{abstract}
Objectives To discover if healthcare professionals working within an ED are able to make a diagnosis of female genital mutilation (FGM) in those patients who have previously undergone the procedure and report it as per UK law.
\end{abstract}

Design A retrospective analysis of patients' notes who were assigned an FGM code during the period of May 2015 to August 2016.

Setting Single-centre, large UK major trauma centre offering a tertiary FGM clinic.

Participants Any woman coded during the study period as having undergone FGM.

Primary outcome Number of FGM cases identified by the ED.

Secondary outcomes Mean age, presenting complaint, discharge diagnosis, genitourinary exam and defibulation status.

Results 34 patients were identified as having undergone FGM, 19 had previously attended ED and none had their FGM identified during their ED attendance. The age range of those identified was 23 to 40 years. None had undergone defibulation.

Conclusion This study demonstrates that the identification of FGM victims by an ED is very poor, and more work needs to be done to increase awareness of the subject by front-line staff.

\section{INTRODUCTION}

Female genital mutilation (FGM), also known as female genital cutting, involves any procedure that includes the removal of any part of the female genital organs for cultural or any other non-therapeutic reason. ${ }^{1}$ Reasons given by supporters of this custom include enhancing marriageability, improving hygiene and ensuring virginity by reducing a woman's promiscuity. ${ }^{2}$ FGM has been reported to occur all over the world with approximately 2 million women undergoing the procedure every year with the highest prevalence in the western and eastern regions of Africa. ${ }^{3}$ In 1997, WHO, Unicef and the United Nations Population Fund (UNFPA) jointly condemned FGM and its practice $^{4}$ supporting other international laws ${ }^{5-7}$ and policies $^{8-10}$ describing it as a human rights violation, torture and an extreme form of violence and discrimination against women. It is estimated that 137000 women in England and Wales have undergone FGM, including 10000 girls under 15 years. ${ }^{11}$

The prevalence of FGM within the UK is increasing owing to immigration of women from countries where it is practised. FGM is illegal in the UK, and any case identified in an individual under the age of 18 years must be reported to the police. On 31 October 2015, section 74 of the Serious Crime Act $2015^{12}$ was added to section 5B of the FGM Act $2003^{13}$ mandating all health and social care professionals within England and Wales to report to the police any 'known' cases of FGM in any woman under 18 years which they discover. Since September 2014, all NHS trusts are required to provide monthly reports and minimum data sets regarding FGM to the Department of Health (DoH). This data is anonymised and reported to NHS Digital (formerly the Health and Social Care Information Centre) for the planning and commissioning of services. ${ }^{14}$

This observational study was designed to determine if patients identified via their hospital coding as having undergone FGM experienced any delay in diagnosis because it was not identified in a previous ED visit.

\section{METHODS \\ Design}

A retrospective review (May 2015-August 2016) of healthcare professionals (HCP) electronic coding of all female patients identified as having undergone FGM. Royal Stoke University Hospital (RSUH) introduced an electronic coding system in May 2015. Ethical approval was deemed not necessary from the Research and Development department.

\section{Study setting and population}

The study was undertaken at RSUH, an acute hospital, designated as a Major Trauma Centre which provides specialist services, including a tertiary FGM service, for over 3 million people. RSUH is on the border of Stoke-on-Trent and Newcastle-under-Lyme in Staffordshire and has over 175000 yearly attendances. The UK census ${ }^{15} 2011$ shows that over $90 \%$ of people living in Stoke-onTrent were born in England, 1.7\% in Pakistan and $0.7 \%$ in Scotland and India. Approximately 76000 refugees/asylum are seekers situated in the West Midlands region, with a small proportion living in the Stoke-on-Trent area.

\section{Study protocol}

RSUH uses I-Portal electronic documentation system (a bespoke database management system providing local browser-based access to electronic health record), and the electronic code Z91.7 was 
Table 1 Data extraction form

\begin{tabular}{|c|c|c|c|c|c|c|c|}
\hline Case no & Age at diagnosis & $\begin{array}{l}\text { ED attendance } \\
\text { prior to diagnosis }\end{array}$ & $\begin{array}{l}\text { Presenting } \\
\text { complaint to ED }\end{array}$ & $\begin{array}{l}\text { No of ED } \\
\text { attendances prior } \\
\text { to diagnosis }\end{array}$ & $\begin{array}{l}\text { Was a GU exam } \\
\text { performed in ED? }\end{array}$ & $\begin{array}{l}\text { Discharge } \\
\text { diagnosis }\end{array}$ & $\begin{array}{l}\text { Undergone } \\
\text { defibulation/additional } \\
\text { information }\end{array}$ \\
\hline
\end{tabular}

GU, genitourinary.

used to identify all patients who have undergone FGM. Once identified, a retrospective analysis of their electronic documentations was undertaken to ascertain where their FMG diagnosis was made, if they had attended ED prior to this diagnosis and if so, was their FGM identified during their ED visit.

In order to ascertain if a patient had attended the ED prior to the date of their FGM diagnosis, the data abstractor reviewed each patient's electronic timeline on I-Portal for evidence of ED attendance. If an attendance was identified, their casualty card (attached as a scanned electronic copy) was examined for any evidence relating to FGM, as well as any additional information required for the data extraction form (table 1). The electronic timeline extends back to 2009 on I-Portal so this was designated as the earliest point for the retrospective review. If the ED notes did not indicate that the diagnosis of FGM was made during that particular attendance, a further search of the hospital notes was made to ascertain where and when the FGM diagnosis was made. Only one data abstractor was used to analyse all the notes owing to the low number of FGM patients identified.

\section{RESULTS}

In total, 34 female patients were identified as having undergone FGM. All 34 of them were diagnosed by RSUH antenatal services. RSUH antenatal service dealt with 8788 female patients during the study period, suggesting a low FGM prevalence at $0.38 \%(34 / 8788)$.

Primary outcome: 56\% (19/34) of the women identified as having undergone FGM were seen in ED prior to their FGM diagnosis by antenatal services. None of the women had documented evidence of FGM in their ED notes. All 34 women originated from countries known to have a high prevalence of FGM.

Secondary outcome: Table 2 represents the data extracted from each of the 19 FGM patient's ED notes following their identification by the antenatal services. The age range was 23-40 years (mean age, 31 years); no patients were identified under the age of 18 years. Forty-two per cent $(8 / 19)$ of the patients presented with symptoms relating to possible complications of FGM (vaginal bleeding, abdominal pain and urinary symptoms). Twenty-one per cent (4/19) of the patients underwent a genitourinary (GU) examination (only one within ED). No evidence of defibulation was recorded. All patients identified as having undergone FGM were referred to a midwife with a special interest in vulnerable women/FGM and follow-up in the FGM specialist outpatient clinic.

\section{DISCUSSION}

No evidence was found to suggest that the HCP who interacted with the 19 women attending ED prior to their diagnosis (by the antenatal services) considered the possibility of FGM. Table 2 demonstrates that many of these women presented with symptoms unrelated to complications of their FGM (such as ear pain or a limb injury) making it almost impossible to link their presenting complaint to previous FGM surgery. For those women with complaints relating to GU or obstetrics and gynaecology $(\mathrm{O} \& \mathrm{G})$ problems, their symptoms were consistent with the majority of other patients who have not undergone FGM, therefore would not raise any 'red flags' for the attending clinician. Regarding those four women who did undergo a GU examination, it can only be speculated that their FGM was subtle and therefore not noticed by the clinician. There was insufficient documentation to comment of whether the patient attended alone or with a family member (possibly making disclosure more difficult). There was no documentation within any of the ED notes relating to increased risk factors for FGM (such as country of origin or asylum seeker status).

A literature review focusing on information for HCP working in an acute setting mainly produced articles relating to those patients under the age of 18 years or for those staff working within O\&G. The information available for those HCP working within ED is limited and mainly comes in the format of local hospital policies, with no uniformity of information or guidance for EDs to follow. It is likely this data will mirror the outcomes of other UK EDs reflecting the challenge of diagnosing FGM in this setting. In order to improve ED staff awareness and discovery of FGM, a Royal College of Emergency Medicine best practice guideline ${ }^{16}$ has been developed which echoes other key organisations such as the $\mathrm{DOH}$, GMC, BMA and other Royal Colleges which recommend the routine screening of women from high-risk areas about FGM. The guideline includes a universal FGM flow chart and reporting tool to aid those staff that come into contact with an adult or child who has undergone the procedure. Online supplementary appendix 1 offers some key advice relating to FGM (including pictorial representation of the different types of FGM) to aid HCP when dealing with this subject.

This study is limited by having been performed at a single centre within a relatively short time frame. As a retrospective study, it is possible that the findings of FGM were discovered but not recorded. Nevertheless, this study highlights the difficulties in identifying victims of FGM in the ED, as they do not often present with a related complaint. The results from this study support the government's current main effort for tackling this problem and should remain as part of a multiagency approach. No agency is fully equipped to deal with the multifactorial needs of an FGM patient, and the importance of information sharing between key practitioners is essential to ensure the safety of those girls potentially at risk of FGM. The main focus for the prevention of FGM lies within the community by promoting a family's responsibilities towards safeguarding and the criminal implications of undertaking such an act for those patients originating from high-risk areas.

\section{CONCLUSION}

This retrospective study shows that within a 16-month period one hospital identified 34 women as having previously undergone FGM. None of these discoveries were made by the ED. This reinforces the current Royal College of Emergency Medicine (RCEM) guidance $^{16}$ that front-line staff should be empowered to recognise and manage patients who are at risk of FGM or who have undergone FGM by routinely asking female patients originating from high-risk areas if they have undergone the procedure. 
Table 2 Secondary outcome data

\begin{tabular}{|c|c|c|c|c|c|c|}
\hline Case no & Age & $\begin{array}{l}\text { No of ED attendances } \\
\text { prior to diagnosis }\end{array}$ & Presenting complaint & $\begin{array}{l}\text { Was GU exam } \\
\text { performed in ED? }\end{array}$ & Admitted to hospital? & Discharge diagnosis \\
\hline 1 & 30 & 2 & $\begin{array}{l}\text { 1) Self-discharge. } \\
\text { 2) Generally unwell—vomiting. }\end{array}$ & $\begin{array}{l}\text { No } \\
\text { Yes (O\&G) }\end{array}$ & $\begin{array}{l}\text { No } \\
\text { Yes (0\&G) }\end{array}$ & $\begin{array}{l}\text { 1) No diagnosis } \\
\text { 2) Hyperemesis }\end{array}$ \\
\hline 2 & 40 & 1 & $1 / 12$ history right foot pain, 24 pregnant. & No & No & $\begin{array}{l}\text { (negative for DVT) } \\
\text { MSK pain }\end{array}$ \\
\hline 3 & 32 & 1 & Painful eye & No & No & Corneal ulcer \\
\hline 4 & 31 & 1 & Mouth pain & No & No & Dental abscess \\
\hline 5 & 37 & 1 & Generally unwell? malaria & No & No & Viral illness \\
\hline 6 & 25 & 1 & 2/52 headaches & No & No & Viral illness \\
\hline 7 & 38 & 2 & $\begin{array}{l}\text { 1) Chest pain } \\
\text { 2) Chest pain }\end{array}$ & $\begin{array}{l}\text { No } \\
\text { No }\end{array}$ & $\begin{array}{l}\text { No } \\
\text { No }\end{array}$ & Non-cardiac chest pain $(\times 2)$ \\
\hline 8 & 32 & 1 & Eye swelling & No & No & Conjunctivitis \\
\hline 9 & 26 & 1 & Severe abdominal pain and PV bleeding & Yes (O\&G) & Yes (O\&G) & Threatened miscarriage \\
\hline 10 & 37 & 2 & $\begin{array}{l}\text { 1) Lower abdominal pain \& spotting } \\
\text { 2) Reattendance same day }\end{array}$ & $\begin{array}{l}\text { No } \\
\text { No }\end{array}$ & $\begin{array}{l}\text { No } \\
\text { No (EPAU next day) }\end{array}$ & $\begin{array}{l}\text { 1) Threatened miscarriage } \\
\text { 2) Threatened miscarriage }\end{array}$ \\
\hline 11 & 35 & 1 & Pain to armpit & No & No & $\begin{array}{l}\text { Infected sebaceous cyst right } \\
\text { axilla }\end{array}$ \\
\hline 12 & 30 & 2 & $\begin{array}{l}\text { 1) N\&V } \\
\text { 2) PV bleeding }\end{array}$ & $\begin{array}{l}\text { No } \\
\text { No }\end{array}$ & $\begin{array}{l}\text { No } \\
\text { Yes (CDU) }\end{array}$ & $\begin{array}{l}\text { 1) Pregnancy } \\
\text { 2) Threatened miscarriage }\end{array}$ \\
\hline 13 & 32 & 4 & $\begin{array}{l}\text { 1) Faint } \\
\text { 2) Limb injury } \\
\text { 3) Chest pain } \\
\text { 4) PV } \\
\text { bleeding \& back pain }\end{array}$ & $\begin{array}{l}\text { No } \\
\text { No } \\
\text { No } \\
\text { Yes (O\&G) }\end{array}$ & $\begin{array}{l}\text { No } \\
\text { No } \\
\text { No } \\
\text { Yes (O\&G) }\end{array}$ & $\begin{array}{l}\text { 1) Syncope } \\
\text { 2) MSK limb injury } \\
\text { 3) Non-cardiac CP } \\
\text { 4) Threatened miscarriage }\end{array}$ \\
\hline 14 & 29 & 2 & $\begin{array}{l}\text { 1) Wrist injury } \\
\text { 2) Abdominal pain and PV bleeding }\end{array}$ & $\begin{array}{l}\text { No } \\
\text { No }\end{array}$ & $\begin{array}{l}\text { No } \\
\text { No }\end{array}$ & $\begin{array}{l}\text { 1) Soft tissue injury } \\
\text { 2) Polycystic ovarian syndrome }\end{array}$ \\
\hline 15 & 27 & 1 & Back pain and urinary symptoms & No & No & Cystitis \\
\hline 16 & 23 & 3 & $\begin{array}{l}\text { 1) Chronic abdominal pain } \\
\text { 2) Abdominal pain and fever } \\
\text { 3) LIF pain and PV bleeding }\end{array}$ & $\begin{array}{l}\text { No } \\
\text { Yes (ED) } \\
\text { No }\end{array}$ & $\begin{array}{l}\text { No } \\
\text { Yes (0\&G) } \\
\text { No }\end{array}$ & $\begin{array}{l}\text { 1) Non-specific abdominal pain } \\
\text { 2) PID } \\
\text { 3) Non-specific abdominal pain }\end{array}$ \\
\hline 17 & 28 & 3 & $\begin{array}{l}\text { 1) Ear pain } \\
\text { 2) Ear pain } \\
\text { 3) Ear pain }\end{array}$ & $\begin{array}{l}\text { No } \\
\text { No } \\
\text { No }\end{array}$ & $\begin{array}{l}\text { No } \\
\text { No } \\
\text { No }\end{array}$ & $\begin{array}{l}\text { Otitis externa } \\
\text { Otitis externa } \\
\text { Otitis externa }\end{array}$ \\
\hline 18 & 26 & 1 & Back pain and urinary symptoms & No & No & Cystitis \\
\hline 19 & 30 & 1 & Limb injury & No & No & MSK injury \\
\hline
\end{tabular}

CDU, clinical decision unit; CP, chest pain; DVT, deep vein thrombosis; EPAU, early pregnancy assessment unit; GU, genitourinary; LIF, left iliac fossa; MSK, musculoskeletal; N\&V, nausea and vomiting; O\&G, obstetrics and gynaecology; PID, pelvic inflammatory disease; PV, per vagina.

Acknowledgements The authors thank Davina Dracocardos and Dr Fidelma O'Mahony for their help with patient identification and the RSUH FGM steering group.

Contributors RJF designed the review, interpreted the data, drafted and revised the manuscript in addition to designing the best practice flow chart and data collection tool. GK provided supervision and jointly revised the final manuscript.

\section{Competing interests None declared.}

Provenance and peer review Not commissioned; externally peer reviewed.

(c) Article author(s) (or their employer(s) unless otherwise stated in the text of the article) 2018. All rights reserved. No commercial use is permitted unless otherwise expressly granted.

\section{REFERENCES}

1 Dorkenoo E. Combating female genital mutilation: an agenda for the next decade. World Health Stat Q 1996;49:142-7.

2 Lockhat H. Female genital mutilation: treating the tears. London: Middlesex University Press, 2004

3 United Nations Children's Fund. Female genital mutilation/cutting: a statistical overview and exploration of the dynamics of change. New York: UNICEF, 2013.

4 WHO. Eliminating female genital mutilation: an interagency statement UNAIDS, UNDP, UNECA, UNESCO, UNFPA, UNHCHR, UNHCR, UNICEF, UNIFEM, WHO, 2008

5 Universal Declaration of Human Rights. General assembly resolution 217: UN Doc, 1948. A/810.

6 Committee on the Rights of the Child. Adolescent health and development in the context of the convention on the rights of the child: CRC/GCI, 2003. General Comment No. 4.
7 Committee on the Elimination of All Forms of Discrimination against Women. General recommendation No. 14, 1990, female circumcision; general recommendation No. 19, 1992, Violence against women; and general recommendation No. 24: Women and health., 1999.

8 United Nations Economic and Social Council (ECOSOC), Commission on the Status of Women. Resolution on the ending of female genital mutilation, 2007. E/ CN.6/2007/L.3/Rev.1.

9 United Nations General Assembly. Declaration on the Elimination of Violence against Women: UN Doc., 1993. A/RES/48/104.

10 Protocol to the African charter on human and peoples' rights on the rights of women in Africa, adopted 11: Assembly of the African Union, 2003(accessed 25 Nov 2005).

11 Macfarlane A, Dorkenoo E. Prevalence of female genital mutilation in England and wales: national and local estimates. . London: City University London in association with Equality Now, 2015:2015. 3-5.

12 Serious crime act, 2015. Chapter 9, Section 74. http://www.legislation.gov.uk/ukpga/ 2015/9/pdfs/ukpga_20150009 en.pdf(accessed 26 Jan 2017)

13 Female genital mutilation act, 2003. Chapter 31.. http://www.legislation.gov.uk/ ukpga/2003/31/pdfs/ukpga_20030031_en.pdf(accessed 26 Jan 2017).

14 Information standards board published SCCI2026 female genital mutilation enhanced dataset information standard. http://www.hscic.gov.uk/isce/publication/ scci2026(accessed 26 Jan 2017).

15 Census United Kingdom. Stoke-on-trent census demographics United Kingdom, 2017 http://localstats.co.uk/census-demographics/england/west-midlands/stoke-on-trent. (accessed 26 Jan 2017).

16 Fawcett R. A universal FGM flowchart and reporting tool: The Royal College of Emergency Medicine, Best Practice Guideline, 2017. http://www.rcem.ac.uk/ docs/RCEM\%20Guidance/FGM\%20-\%20BP\%20Guide\%20-\%20Jul\%202017. pdf(accessed 24 Jan 2017) 